\title{
Pengaruh Alat Permainan Edukatif Tangram dalam Meningkatkan Pemahaman Konsep Geometri di TK Qurrota A'yun Ponorogo
}

\author{
Rosda Ayu Fitria ${ }^{1 凶}$, Suyadi $^{2}$ \\ Pendidikan Anak Usia Dini, Universitas Islam Negeri Sunan Kalijaga, Yogyakarta, Indonesia \\ DOI: $10.31004 /$ aulad.v4i1.90
}

$\checkmark$ Corresponding author:

[rosdaayu96@gmail.com]

\section{Article Info}

Kata kunci:

Alat Permainan Edukatif,

Tangram,

Geometri.

\section{Abstrak}

Pemahaman geometri pada anak usia dini sangatlah penting karena dalam kehidupan nyata banyak ditemukan di lingkungan sekitar yang berkenaan dengan geometri. Dengan demikian untuk mempermudah penyampaian materi tersebut menggunakan alat bantuan APE tangram. Penelitian ini menggunakan pendekatan kuantitatif quasi eksperimen dengan jumlah sampel 33 anak. Dengan instrumen diambil dari pre-test dan post test. Hasil uji hipotesis menunjukkan, terdapat perbedaan pemahaman konsep geometri pada kels eksperimen dan kelas kontrol.

\section{Abstract}

Understanding geometry in early childhood is very important because in

Keywords:

Education game tools,

Tangram,

Geometry. real life there are many found in the surrounding environment with regard to geometry. Trus to facilitate the delivery of the material using in the form of educational game tools tangram. This study used quantitative approach quasi experiments with a sample number of 33 children. With instruments taken from pre-test and post-test. The results of the hypothesis test showed that there were differences in understanding of geometric concepts in the experimental class and control class.

\section{PENDAHULUAN}

Pendidikan merupakan salah satu proses pembelajaran yang dirancang agar terwujudnya suasana serta proses pembelajaran yang diharapkan, dengan begitu peserta didik dapat berperan aktif untuk bisa mengembangkan segala potensi dalam dirinya serta memperkuat diri, spiritual keagamaan, pribadi, kecerdasan, akhlak mulia dan pula keterampilan yang nantinya diharapkan dapat berguna untuk diri mereka, masyarakat, bangsa pula negara, penjelasan pada (UU Sisdiknas No 20 Tahun, 2003 butir 1). Salah satu usaha yang terlaksana berupa adanya satuan pendidikan yang terdiri dari pendidikan formal, nonformal serta pendidikan informal yang tersedia dalam setiap jenjang dan jenis pendidikan. Adapun salah satu perwujudan dalam jenjang pendidikan formal berupa pendidikan Anak Usia Dini. 
Pada pernyataan diatas dapat kita pahami serta simpulkan, segala pendidikan yang kita sampaikan kepada anak haruslah dijadikan dasar yang kuat untuk nantinya dapat terwujud pendidikan yang lebih tinggi bagi anak. Dengan begitu pula sebagai pendidik kita perlu memberikan stimulus yang baik dan sesuai terhadap segala kondisi dan keadaan dalam diri anak agar segala pertumbuhan dan perkembangan pada diri anak bisa berkembang secara baik dan tepat. Pada anak usia dini sangat penting memberikan stimulus untuk perkembangkan anak usia dini, dimana pada saat tersebut otak akan semakin berkembang apabili stimulus yang diberikan semakin banyak. Anak juga memerluka lingkungan yang dapat merangsang pertumbuhan otak dengan selalu mendapat stimulus yang baik dan positif.

Setiap stimulus yang diperlukan anak berbeda-beda sehingga membuat para pendidik memiliki cara-cara tersendiri dalam menstimulasi anak. Di negara Indonesia memilik kurikulum yang di khususkan untuk pendidikan anak usia dini. Dengan kurikulum tersebut dapat dijadikan acuhan untuk mengasah dan menggali setiap potensi yang dimiliki oleh anak. Adapun aspek yang harus dikembangkan sesuai dengan kurikulum pendidikan anak usia dini meliputi, motorik, kognitif, emosional, bahasa, seni dan nilai-nilai moral. Salah satu perkembangan yang harus di stimulus sebaik mungkin yaitu perkembangan kognitif pada anak usia dini. Dalam mengembangkan kognitif pada anak usia dini meliputi warna, bentuk, ukuran, klasifikasi dan seri Beaty (Maxim, 1993)

Adapun indikator perkembangan kognitif pada anak usia 4-5 tahun dalam memahami konsep geometri yaitu: mengelompokkan bentuk-bentuk geometri (lingkaran, segitiga, segiempat) dan menyebutkan kembali bendabenda yang menunjukkan bentuk bentuk geometri (Pusat Kurikulum Diknas,2007).

Stimulus pemahaman geometri dengan media dapat diberikan dengan memasukkan materi pembelajaran pada permainan edukatif pada anak usia dini sehingga anak antusias untuk mengikuti permainan edukatif tersebut. Permainan edukatif, merupakan sebuah permainan yang di dalamnya mengandung unsur pembelajaran, ataupun yang dapat guru pergunakan sebagai sarana dalam bermain dan belajar, dan dimana dapat mengembangkan seluruh aspek kemampuan pada anak secara optimal. (Adib, 2011). Dalam penelitian ini peneliti menggunakan APE tangram sebagai media pembelajaran geometri bangun datar. (NN Mufti, 2020) Tangram merupakan suatu permainan dari China berbentuk puzzle yang terdiri dari tujuh keeping bangun datar yang terdiri dari persegi, segitiga dan jajar genjang.

Menurut Rohani (Ahmad 1997) memaparkan bahwasanya media pembelajaran ialah sebuah sarana agar dapat mempermudah para pengajar dan peserta didik dalam berkomunikasi yang baik ketika memulai pembelajaran. Arsyad dikutip oleh (Mufti dan Pranata 2020) menyatakan media pembelajaran merupakan suatu media yang dapat menyampaikan pesan serta informasi akurat dan sesuai dengan materi ajar dengan tujuan pemahaman dan mengandung maksud untuk menyampaikan pengajaran.

Adapun manfaat dalam penggunaan APE tangram bagi anak dijelaskan Suryani (2018) sebagai berikut; 1) dapat merangsang rasa ingin tahu untuk belajar pada anak, 2) memotivasi anak didik untuk bisa belajar dengan baik di kelas secara mandiri, 3) dapat memberikan kemudahan pada peserta didik untuk dapat menelaah materi pembelajaran yang telah sampaikan secara sistematis menggunakan tangram, 4) dapat menumbuhkan suasana yang menyenangkan serta tidak membuat anak bosan dan dapat belajar dengan fokus, 5) dapat mengembangkan kreativitas peserta didik, dan dapat menguji keterampilan, daya pikir anak dan mengenalkan bidang datar kepada peserta didik.

Mainan merupakan sebuah objek untuk dapat dimainkan (Suyadi dan Selvi 2019), dengan bermain dan pemilihan alat permainan dapat mengembangkan segala perkembangan pada anak Maka dari itu pemilihan media pembelajaran atau mainan yang akan digunakan harus memperhatikan pada kondisi anak didik, dan hal terpenting dalam pemilihan permainan adalah segi keamanan, termasuk ketika ingin memilih media pembelajaran yang akan digunakan dalam mengenalkan geometri pada peserta didik, dengan demikian peneliti memilih Alat Permainan Edukatif berupa tangram pada media pembelajaran geometri yang dianggap sesuai dengan materi. Alat permainan edukatif tangrang dianggap mampu membantu peserta didik untuk memahami konsep geometri, hal itu dikarenakan APE tangram tidak hanya sebagai media pembelajaran akan tetapi juga dapat digunakan sebagai alat permainan sehingga dianggap cocok digunakan sebagai media pembelajaran pada anak usia dini.

Berdasarkan fenomena-fenomena yang terjadi di lapangan yaitu kurangnya pemahaman pada diri anak tentang konsep geometri seperti bentuk segitiga, persegi, jajaran genjang, persegi panjang, trapesium, layang-layang serta lingkaran yang ada pada pembelajaran anak usia dini. Fenomena tersebut dapat disebabkan karena guru kurang mengemas proses pembelajaran melalui kegiatan bermain, dikarenakan guru lebih sering menugaskan pada anak didik untuk proses pembelajaran dalam bentuk penugasan berupa majalah, kurangnya pengetahuan guru terhadap media pembelajaran yang sesuai terhadap kondisi anak sehingga pengembangan mengenai bentuk geometri pada diri anak sangatlah kurang dan rendah. (Mufti dan Pranata 2020).

Pada penelitian yang akan dilakukan peneliti maka mengambil fokus pada materi geometri bangun datar untuk Pendidikan anak. Geometri menjelaskan salah satu materi pokok pada pembelajaran matematika. Matematika merupakan salah satu disiplin ilmu yang memiliki kriteria khusus (Nisa 2020) sama halnya pada geometri Pada KBBI menyatakan bahwa geometri dapat diartikan sebagai salah satu cabang ilmu matematika yang menjelaskan sifat pada garis, sudut, bidang, dan ruang. "Sejalan dengan pembelajaran matematika, pemahaman pada proses pengajaran geometri dalam setiap jenjang pendidikan dasar bertujuan sebagai acuan dalam pemahaman dan 
pembentukan sikap pada anak didik, juga pada penerapan dan keterampilan geometri". (Taulany, Putra, dan Wibisono 2020)

Adapun manfaat mengenalkan geometri bangun datar pada anak usia dini sesuai dengan pendapat Sianturi ialah; 1) memberikan rangsangan pada otak anak usia dini dengan bentuk-bentuk geometri yang bermacam-macam, 2) menambah ilmu pengetahuan, 3) melampaui batas ruang kelas, 4) membangun minat bakat yang sesuai dengan diri anak didik, dan 5) menjadi motivasi bagi anak untuk lebih giat belajar.

Alat permainan edukatif berupa media yang dapat digunakan dalam memudahkan anak untuk memahami pembelajaran geometri adalah media "Tangram" dimana media ini berupa permainan yang berasal dari negeri china yang dikemas dalam bentuk puzzle serta memiliki tujuh keping bentuk bangun datar yang berupa bentuk geometri berupa lima buah segitiga, satu buah persegi, serta satu jajaran genjang. Dari kepingan tangram ini dapat kita susun serta tempel menyerupai bentuk-bentuk yang anak sukai, seperti gambar kucing, rumah, petani dan masih banyak bentuk lainnya yang di senangi anak. Dalam proses penelitian ini peneliti dapat mengetahui seberapa perbedaan APE Tangram yang diterapkan pada kelas eksperimen dan kelas control yang tidak menggunakan APE tangram dalam pembelajaran geometri bangun datar pada anak usia dini.

\section{METODOLOGI}

Metodologi dalam pendekatan ini berupa pendekatan kuantitatif dengan jenis penelitian ekspermen, supaya dapat mengukur seberapa besar dampak yang terlihat dari variabel bebas terhadap variabel terikat. Adapun variabel bebas $(X)$ alat permainan edukatif tangram terhadap variabel terikat $(Y)$ pemahaman konsep geometri. pada penelitian ini Peneliti memilih untuk menggunakan desain Quasi Eksperimental, berupa Noneequivalent Control Group Designt yang terdiri atas dua kelompok, pertama kelompok eksperimen dan kedua kelompok kontrol sebagai pembanding. Dilakukan pre test ntuk mengetahui bagaimana kondisi awal terhdap kedua kelompok. Kemudian kelompok eksperimen diberikan treatment menggunakan alat permainan edukatif berupa tangram dan pada kelompok kontrol tidak diberikan treatment menggunakan alat permainan edukatif tangram. Setelah diberikan treatment untuk mengetahui kemampuan akhir dalam pemahaman konsep geometri pada proses pembelajaran yang diberikan kepada anak usia dini berupa post test.

Subjek yang diambil pada penelitian ini mengambil sampel anak usia dini dengan kelompok A di TK Qurrata'ayun Ponorogo pada kelas A1 dan kelas A2 dengan jumlah 33 anak. Dengan kelas A1 sebagai sampel dari kelas experimentt dan kelas $A 2$ sebagai sampe terhadap kelas kontrol. Teknik dalam pengumpulan data yang dipakai serta dipergunakan oleh peneliti dalam penelitian ini berupa observasi dan dokumentasi. Uji validitas dan uji homogenitas harus didahulukan ketika hendak menganalisis data. Cara melakukan Uji validitas bisa dilakukan dengan cara peneliti membandingkan nilai hitung corrected item-total correlation beserta nilai tabel statistik dengan banyaknya data yang dapat digunakan.

\section{HASIL DAN PEMBAHASAN}

Penelitian ini mengggunakan uji validasi dengan mengkorelasikan antara setiap satu nilai item dengan keseluruhan nilai total. Kemudia hasil dari uji validitas yang diperoleh oleh semua item dapat dinyatakan valid dengan $r$ hitung $>r$ tabel. Setelah itu dilanjut dengan uji prasyara berupa uji normalitas dan uji homogenitas, uji normalitas didapatkan dari nilai sig. 0,680 dimana 0,680 >0,05 sehingga data tersebut dinyatakan normal. Kemudian dilanjut dengan uji homogenitas, pada uji homogenitas diperoleh 0,328 dimana 0,328 > 0,05 sehingga data dinyatakan homogen, dan dapat lanjut menggunakan analisis data uji t.

Tabel 1. Nilai posttest terhadap kelas eksperimen dan kelas kontrol Group Statistics

\begin{tabular}{|c|c|c|c|c|c|}
\hline & Kelompok & $\mathrm{N}$ & Mean & Std. Deviation & $\begin{array}{l}\text { Std. Error } \\
\text { Mean }\end{array}$ \\
\hline TANGRAM & $\begin{array}{l}\text { KELAS EKSPERIMEN } \\
\text { KELAS KONTROL }\end{array}$ & $\begin{array}{l}17 \\
16\end{array}$ & $\begin{array}{l}42,35 \\
33,13\end{array}$ & $\begin{array}{r}6,234 \\
8,694\end{array}$ & $\begin{array}{l}1,512 \\
2,173\end{array}$ \\
\hline
\end{tabular}

Berdasarkan tabel 1 dapat kita lihat perbedaan hasil rata-rata yang didapat pada post test kelas eksperimen dan juga kelas kontrol. Jumlah responden dikelas eksperimen sebanyak 17 (tujuh belas) anak dengan perolehan nilai rata-rata 42,35 dan hasil dari standar deviasi 6,234. Serta dari jumlah responden pada kelas kontrol sebanyak 16 anak dengan perolehan nilai rata-rata 33,13 dan hasil keseluruhan standar deviasi 8,694. Adapun hasil terhadap analisis data penelitian ini dapat dilihat dalam tabel 2.

Dari hasil output tabel 2 independent sampel test, pada bagian equal variances assumed didapatkan nilai signifikan (2-tailed) adalah 0,001 < 0,05 dan nilai thitung > tabel yakni 3,520 > 2,042 dapat kita simpulkan bahwasnya $\mathrm{H}_{0}$ tidak diterima serta $\mathrm{H}_{1}$ dapat diterima, artinya ada perbedaan nyata (Signifikan) antara kelas eksperiman dalam menggunakan APE Tangram pada pemahaman geometri bangun datar dengan kelas kontrol yang tidak menggunakan APE Tangram dalam pemahaman geometri bangun datar. Jika mengacu pada tabel koefisien didapat 
kesimpulan bahwa pada kelas eksperimen memperoleh nilai mean 42,35 memiliki makna anak lebih paham materi geometri bangun datar dengan APE Tangram dari anak pada kelas kontol tidak menggunakan APE Tangram yang memiliki nilai mean 33,13.

\section{Tabel 2. Independen Samples Test}

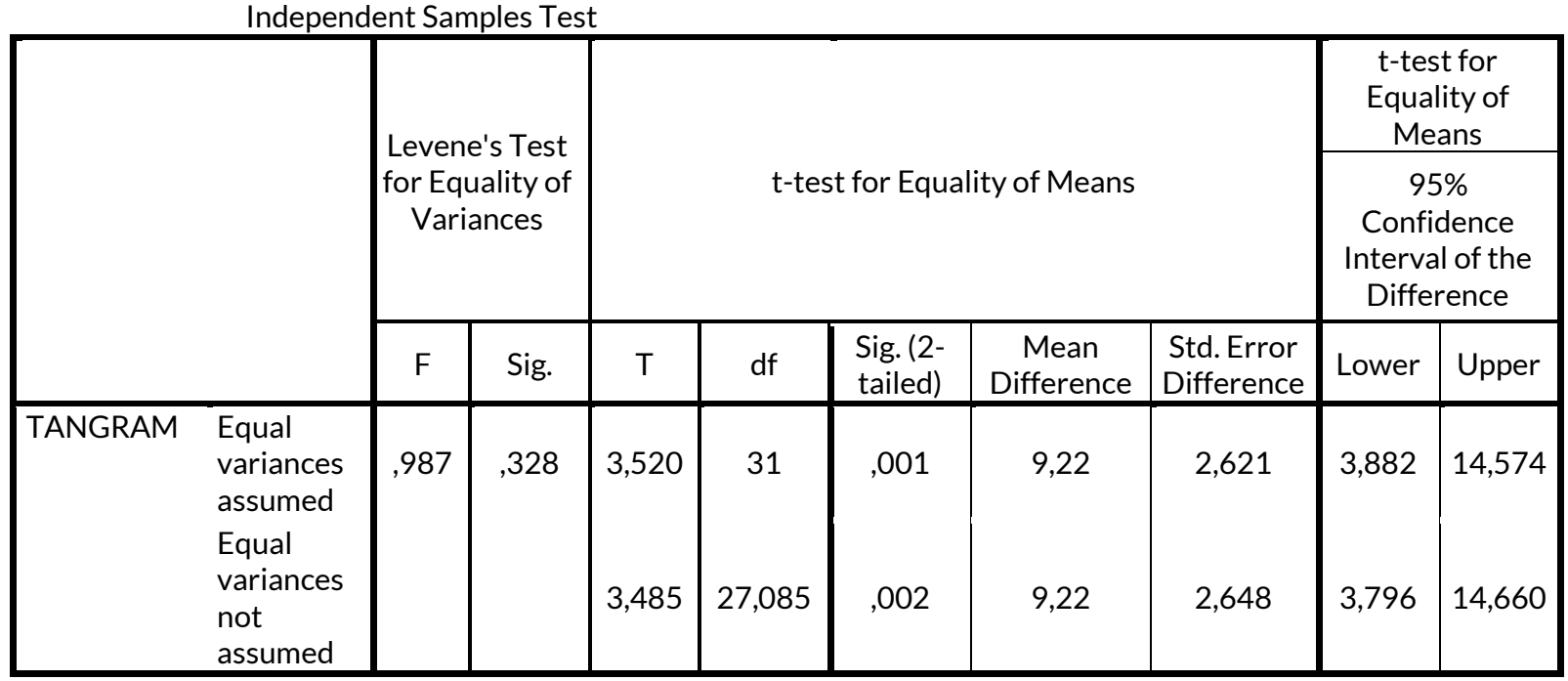

Selanjutnya, pada tabel mean difference diketahui nilai selisih perbedaan jelas antara kelas eksperimen yang menggunakan APE Tangram dan kelas kontrol dimana tidak dengan APE Tangram. Yang mana perbedaanya sebesar 9,22. Angka ini berasal dari rata-rata nilai pemahaman geometri, yaitu $42,35-33,13=9,22$.

Hasil yang didapat pada penelitian ini dapat menjelaskan ada kebenaran temuan terhadap penelitian terdahulu dimana menjelaskan bahwasanya pada saat menggunakan alat permainan edukatif berupa tangram ini dapat meningkatkan pemahaman serta kemudahan dalam pengenalan mengenai konsep geometri pada anak. Pada penelitian lainnya juga memberikan saran bahwa alat permainan edukatif amatlah penting untuk bisa dipergunakan pendidik sebagai sarana dalam pembelajaran.

Bersamaan dengan penelitian yang telah dilakukan oleh (Fitriana t.t.)beliau menjelaskan bahwa terdapat perbedaan dalam pengenalan konsep geometri ketika sebelum serta sesudah menggunakan alat permainan edukatif berupa tangram pada anak usia dini. Karena jika anak diberikan permainan yang di dalamnya mengandung unsur edukatif maka dapat membantu mengoptimalkan perkembangan pada diri anak dan dapat melatih daya ingat dalam diri anak. Selain itu hasil penelitian (Perdana 2020) menyimpulkan adanya perbedaan yang terlihat pada anak pra sekolah antara anak yang mendapatkan stimulasi alat permainan edukatif dan anak yang tidak mendapatkan stimulasi dengan alat permainan edukatif.

Pembelajaran yang diterapkan pada anak seharusnya dilakukan dengan cara anak bermain sambil mereka belajar. Permainan adalah kegiatan yang dapat menghasilkan serta menyenangkan bagi diri anak, dengan cara anak bermain anak akan dengan mudah menemukan hal-hal baru yang dapat memperkuat pengetahuan mereka sebelumnya dengan cara mengeksplorasi dan berekspresi, yang dapat menunjukkan jati diri serta kreativitas anak.

Guru adalah sebuah profesi yang dimana sangat berperan dalam mempengaruhi belajar peserta didik. Dengan kemampuan serta strategi yang dilakukan oleh guru kepada anak usia dini maka akan tumbuh dan berkembangnya kecerdasan yang dimiliki peserta didik(Babuta dan Rahmat 2019)guru juga sangat berperan sebagai orang tua jika sudah dapat terjun dalam dunia anak. (Purwanto dkk. 2020) Sebagai pembimbing anak usia dini tentunya tidaklah sama dengan jenjang pendidikan lainnya, kasus pada anak usia dini yang belum bisa seutuhnya memahami perintah, serta anak usia dini memiliki keunikan dimana terdapat perbedaan antara satu anak dengan anak lainnya, dengan begitu guru harus bisa memahami karakter setiap anak didiknya, guna memudahkan dalam mengarahkan dan mengembangkan kecerdasan pada setiap anak didik.

Salah satu kegiatan yang dilakukan untuk memudahkan guru untuk menyampaikan materi secara menarik bisa menggunakan media serta alat permainan edukatif.(Astini, Nurhasanah, dan Nupus 2019)memaparkan bahwa alat permainan edukatif merupakan berbagai macam peralatan serta benda yang dapat dipergunakan untuk bermain. Dimana menggunakan Alat permainan Edukatif dapat menstimulasi seluruh kemampuan pada anak dapat berkembang dengan baik sesuai perkembangannya. Alat bermain adalah sebuah media untuk bisa merangsang aktivitas kesenangan anak dengan berbagai sarana yang disediakan (Puspitasari 2017) Alat Permainan Edukatif berupa tangram ini merupakan alat permainan dimana dapat meningkatkan sera merangsang pada proses pembelajaran serta dapat diterima oleh anak. (Selvi dan Wulantaka 2020). Adapun dokumentasi yang diambil pada penelitian ini dapat dilihat pada gambar 1 sampai 3 . 


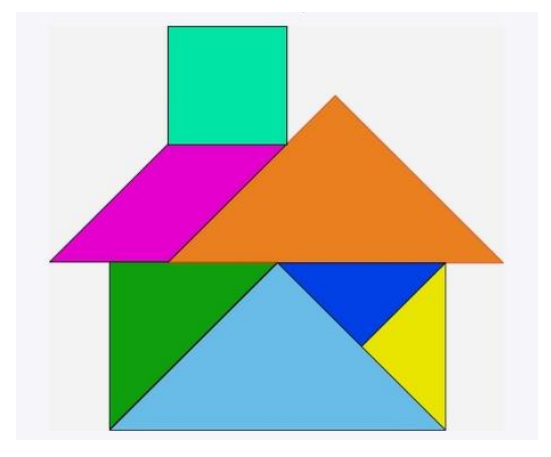

Gambar 1. APE Tangram

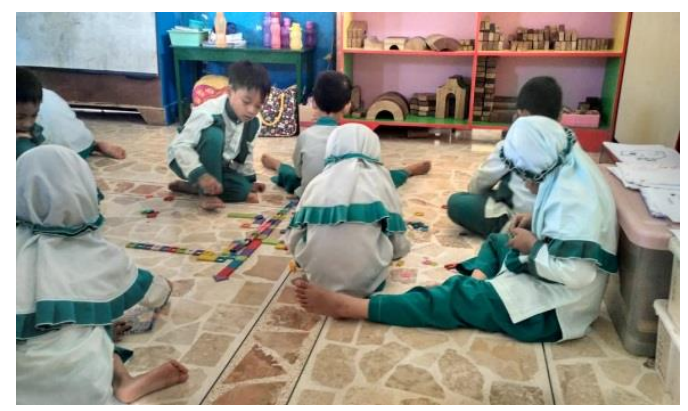

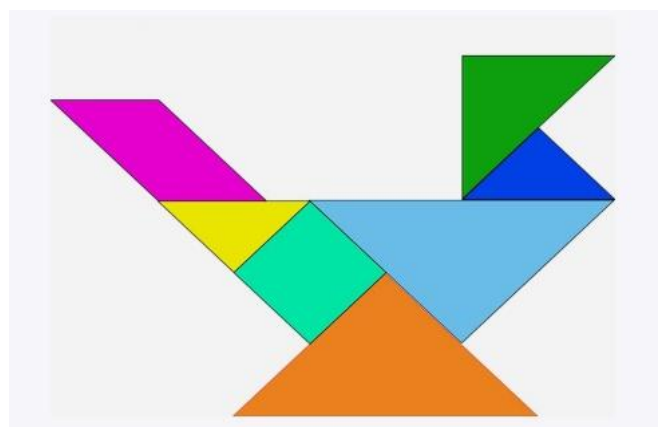

Gambar 2. APE Tangram

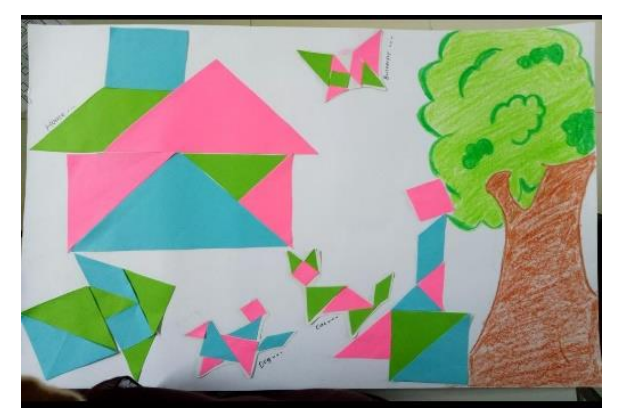

\section{KESIMPULAN}

Gambar 3. Pemahaman geometri dengan APE Tangram

Perbedaan yang nyata terlihat pada kelas eksperimen yang menggunakan APE Tangram dalam pemahaman geometri bangun ruang dengan kelas kontrol yang tidak menggunakan APE Tangram dalam pemahaman geometri bangun ruang pada anak usia dini. Adapun hasil yang didapat pada saat pengolahan data dimana pengolahan ini menggunakan SPSS 18.0 For Windows nilai signifikan (2-tailed) adalah 0,001<0,05, nilai thitung $>t_{\text {tabel }}$ berupa 3,520 > 2,042. tabel koefisien didapat pada kelas eksperimen memperoleh nilai mean 42,35 memiliki makna anak lebih paham materi geometri bangun datar dengan APE Tangram dari anak pada kelas kontol tidak menggunakan APE Tangram yang memiliki nilai mean 33,13. Manfaat dari penelitian ini yaitu untuk mengetahui media apa yang dapat digunaka oleh guru dalam mengemas pembelajaran anak usia dini.

\section{DAFTAR PUSTAKA}

Ahmad, Rohani. 1997. Media Intruksional Edukatif. Jakarta: PT Rineka Cipta.

Aqib. 2011. Pedoman Teknis Penyelenggaraan Pendidikan Anak Usia Dini (PAUD). Bandung: Nuansa Aulia.

Astini, Baik Nilawati, Nurhasanah Nurhasanah, dan Hayatun Nupus. 2019. "Alat Permainan Edukatif Berbasis Lingkungan Untuk Pembelajaran Saintifik Tema Lingkungan Bagi Guru Paud Korban Gempa." Jurnal Pendidikan Anak 8(1):1-6. doi: 10.21831/jpa.v8i1.26760.

Babuta, Asma Is, dan Abdul Rahmat. 2019. "Peningkatan Kompetensi Pedagogik Guru Melalui Pelaksanaan Supervisi Klinis Dengan Tektik Kelompok." AL-Tanzim : Jurnal Manajemen Pendidikan Islam 3(1):1-28. doi: 10.33650/al-tanzim.v3i1.496.

Fitriana, Desy Ayu. t.t. "Pendidikan Guru Pendidkan Aank Usia Dini Fakultas IImu Pendidikan Universitas Negeri Semarang 2019."

Mufti, Nasisah Nada, dan Oyon Haki Pranata. 2020b. "Studi Literatur: Tangram Sebagai Media Pembelajaran Geometri." 5:7.

Nisa, Halimatun. 2020. “Mengatasi Kesulitas Belajar Matematika Anak Usia Sekolah Dasar Dengn Pendekatan Psikologi Kognitif." 16(1):8.

Perdana, Novrian Satria. 2020. "Analisis Biaya Satuan Operasional Penyelenggaraan Taman Kanak-Kanak Holistik Integratif." Jurnal Obsesi : Jurnal Pendidikan Anak Usia Dini 5(1):187. doi: 10.31004/obsesi.v5i1.501.

Purwanto, Agus, Ardian Sopa, Riza Primahendra, Sekundina Williana Kusumaningsih, dan Rudy Pramono. 2020. "Pengaruh Gaya Kepemimpinan Transaction, Trasformational, Authentic dan Authortarian Terhadap Kinerja Guru Madrasah Tsanawiah di Kudus." AL-TANZIM: Jurnal Manajemen Pendidikan Islam 4(1):7080. doi: 10.33650/al-tanzim.v4i1.938. 
Puspitasari, Cita. 2017. "A New Tool to Facilitate Learning Reading For Early Childhood." 5(3):15.

Selvi, Issaura Dwi, dan Nazauma Nareswara Wulantaka. 2020. "Pengembangan Kreativitas Dan Alat Permainan Edukatif Anak Usia Dini Dalam Perspektif Atribut Dan Organisasi." 9(1):8.

UU Sisdiknas No 20 Tahun, 2003 butir 1.

Suryani. 2018. Media Pembelajaran Inovatif. Bandung: PT Rosdakarya.

Suyadi, Suyadi, dan Issaura Dwi Selvi. 2019. "Implementasi Mainan Susun Balok Seimbang Berbasis Kearifan Lokal Yogyakarta untuk Anak Usia Dini." Jurnal Obsesi : Jurnal Pendidikan Anak Usia Dini 4(1):385. doi: 10.31004/obsesi.v4i1.345.

Taulany, Himmah, Lisa Virdinarti Putra, dan Iwan Setiawan Wibisono. 2020. "Media Tangram Geometri 'Let's Be Healthy' Berbasis Android untuk Meningkatkan Kemampuan Berpikir Geometri Anak Usia Dini." Jurnal Obsesi : Jurnal Pendidikan Anak Usia Dini 4(2):676. doi: 10.31004/obsesi.v4i2.365. 